\title{
'One walked of course with one's eyes greatly open' (Henry James): London Sights in Alvin Langdon Coburn, Henry James and Joseph Pennell
}

\section{Douglas Tallack (University of Leicester, UK) ${ }^{1}$}

'A city must remain open to knowing that it does not yet know what it will be' (Jacques Derrida).

'To suppress the appearance would be to abolish social relations' (Étienne Balibar).

For some twenty years, either side of the turn of the twentieth century, dramatic population growth, perplexing forms of spatial expansion, and the international promotion of cities posed questions about how cities could be known. New disciplines and sub-disciplines, as well as institutions, were founded to come up with answers, while many artists and writers also became preoccupied with facets of urban knowledge. 'One walked, of course, with one's eyes greatly open', Henry James disingenuously remarks in the Preface to The Princess Casamassima. $^{2}$

A trio of Americans, Alvin Langdon Coburn (1882-1966), Henry James (1843-1916), and Joseph Pennell (1857-1926), were demonstrably attracted to London. Their photographs, writings and drawings, respectively, speculate about its temporal, spatial and phenomenological thresholds: where the city begins and ends; how the visible and invisible (or hidden) dimensions of the city abut each other; and how part and whole relate, and according to what measure and from what point of view. Although their professional associations are a convenient rationale for this essay, ${ }^{3}$ it is the interplay of phrases, anecdotes, narratives, frames, and perspectives, across written and visual forms that open up what are, in the end, intriguing theoretical insights. Coburn, James and Pennell came up 
against a challenge central to modernity: how to represent not simply what could be seen but also the hidden forces that have shaped a city, and would continue to shape it into the future. London had a population of nearly six million people, was the capital of the British Empire, and was engulfing surrounding towns, while continuing to extend its influence internationally. Accordingly, though not straightforwardly, London precipitated debates over representation, located, at that time, along the shifting fault-line between Realism and Modernism. It also occasioned apprehension about the urban future. Near the end of E. M. Forster's Howards End (1910), Helen Schlegel observes that 'London's creeping', as the 'red rust' of a previously invisible city appeared on the horizon. 'And London is only part of something else', she adds. Friedrich Engels, writing more than half a century before, supplies a corresponding perspective from within its boundaries:

A town, such as London, where a man may wander for hours without reaching the beginning of the end, without meeting the slightest hint which could lead to the inference that there is open country within reach, is a strange thing. ${ }^{4}$

Coburn, James and Pennell were intrigued by the phenomenon of the city, even as they focussed on individual cities. Among other cities, James wrote about New York, earlier and later in his career in Washington Square (1880) and The American Scene (1907), and Venice and Florence in essays from the 1870s to 1890 s collected in Italian Hours (1909). He reserved some of his most melodramatic pronouncements for London, 'the murky modern Babylon' of his 1888 essay, 'London', and went on to explore the 'deepest abyss of all the wonderments that break out for the student of great cities', as he put it in the Preface to In the Cage (1898). In this and other Prefaces, he reconsidered the cities of some of his fiction in the company of Alvin Langdon Coburn, during their deliberations over what would make appropriately symbolic frontispieces for The Novels and Tales of Henry James, better known as the New York Edition (190709). Their association enhanced Coburn's Modernist credentials, at a time when 
he, too, was embarking on an exploration of cities that would shortly culminate in a selection of striking photographs for two books, London, which appeared in quite different versions in 1909 and 1914, and New York (1910), and in unrealised plans for a book to be entitled The Adventures of Cities. Joseph Pennell's visual explorations of two cities, in particular, are now appreciated independently from his many commissions to illustrate essays and fiction. Sidney Dark wrote a supporting text for London (1924), containing fifty-five drawings, dating from 1908, but never before reproduced. Pennell's New York Etchings, a collection of ninety prints from the Picker Art Gallery, was published in 1980. It is germane to one of the strands in this essay to note that Pennell's style changed, shortly after he contributed illustrations to James's 'London', becoming more Impressionistic and loosely Modernist throughout the 1890s. This accorded with his stout defence of drawing and painting against photography's aesthetic advances. When James's essay was reprinted in English Hours in 1905, accompanied by a few more London essays, Pennell provided a completely new set of illustrations. ${ }^{5}$

For a start, James has to get himself across the threshold into London from somewhere else, a process that makes one pause to think whether any comparable conundrum confronts visual artist when framing a city sight and drawing limits. In the single essay, 'London', an account of the city that he had lived in since 1876, there is a good deal of getting there, just as, in 'An English Easter' (1877), James is three-quarters through an essay about a visit to Rochester, Canterbury and Dover and has still not left London. 'The sense of approach' to London jolts him over breakfast at the Adelphi Hotel in Liverpool, shortly after docking, and he prolongs his meditation by taking 'the slowest of Sunday trains, pottering up to London', and then spinning out 'virtually a first impression' in the cab that takes him and his luggage from Euston to Morley's Hotel, Trafalgar Square. There is a tension between James's growing sense of 
himself as an author, and one who is particularly at home in cities, and the counterweight of London. The former comes out most strongly, if still ambiguously in the Prefaces to the New York Edition near the end of his career, but authorial power is evident in this early essay in his highly self-conscious capturing of London in a phrase. Set against James's rhetorical assertions, however, is his acknowledgement of London as, seemingly, preoccupied with its own past, present and future, and with what James, from time to time, invokes as its 'laws', meaning the manifestation of hidden forces.

James also expands his authority over the city by skillfully manipulating narrative time in the essay. He locates the city's present, the 'now' of London, by bringing his own story up to date. In effect, he ushers the reader into his own present:

Practically, of course, one lives in a quarter, in a plot [of the city]; but in imagination, and by a constant mental act of reference, the sympathizing resident inhabits the whole - and it is only of him that I deem it worth while to speak.

In re-introducing himself as a London resident for over a decade, and putting to one side the visitor that he had earlier been, James assuredly crosses the threshold and fully enters the city, taking possession of it in the present tense. More than this, though, James seeks to create the necessary margin from which, in a moment of insight, he can bring together the part and the whole of the city:

[The resident] fancies himself, as they say, for being a particle in so unequalled an aggregation; and [London's] immeasurable circumference, even though unvisited and lost in smoke, gives him a sense of social and intellectual elbow-room. $^{6}$

At about the time when 'London' was re-published in English Hours (1905), with Joseph Pennell's new drawings for all of the essays, James initiated a collaboration with Alvin Langdon Coburn. Those years overlapped with what Mike Weaver calls Coburn's 'Symbolist period, in which he made his great 
contribution to photography'. ${ }^{7}$ James threw himself into his work with Coburn, perceiving a synergy with the photographer's symbolist aesthetic, which he bolstered with robust instructions: 'Once you get the type into your head, you will easily recognise specimens by walking in the old residential and 'noble' parts of the city'. ${ }^{8}$ They worked most closely on the five London photographs, but it is illuminating to bring two of these together with a selection of other Coburn photographs of London from the same period. These photographs, accompanied, where it is helpful, by James's commentary, test their common ambition to cross the urban threshold by means of a symbolic aesthetic that proposes to unite the visible and the invisible aspects of a city.

The 'unequalled aggregation' and 'immeasurable circumference' of London is not approached narratively by Coburn, as it is, however circuitously, by James in the opening pages of 'London', when he establishes his right to residency and, with it, to an overview. Instead, Coburn opts for a pictured totality, in line with his emerging symbolist aesthetics. In St. Paul's from Ludgate Circus (1905), the cathedral is given centrality because it over-shadows the foreground, other than where smoke blocks the view, and out-shines the other domes and steeples on the skyline. In St. Paul's from the River (c. 1906) ${ }^{9}$ and also in The Dome of St Paul's (c. 1906), which is the photograph James approved as the frontispiece to The Princess Casamassima (1886) (see figure 1), the pictorial and historical authority of the dome is confirmed by the use made of the River Thames.

In many of his cityscapes, as well as his landscapes, Coburn follows the example of pictorial photography and seeks out and enhances what he calls the 'liquid surfaces', produced by light on water. The language of 'presentment', 'recognition', 'transfiguration', and 'type' used by James to guide Coburn in his search for appropriate images is entirely apposite, and not simply for Coburn's local commission, but equally, for Coburn's preferred pictorialism and its maturation into a symbolist aesthetic. Thus, a patch of light on the River Thames 
in St. Paul's from the River sits directly under St. Paul's and an arch of the old Waterloo Bridge. The lit-up river, prominent, too, in The Dome of St. Paul's (1905-06) consigns other aspects of the scene to the static margins, while serving to reinforce the Cathedral as a symbol of London's soul. In 1935, Coburn retrospectively generalised his aesthetic:

One by one material things come to be known for what they are, beautiful symbols of still more beautiful Realities. One by one they are taken into the mind and their outward forms transcended until in the end only the Realities themselves are contemplated, and at last the soul comes to behold the One Reality face to face, and symbolism is overpassed. For Mike Weaver, building on Coburn's pronouncement, St. Paul's from the River exemplifies a hierarchy of interpretation:

[It] may be read at several levels. Literally, it is a picture of St. Paul's Cathedral, Waterloo Bridge, and the River Thames. Figuratively, it unites a dome, a bridge, and a river. Allegorically, it offers a dome of knowledge, supported on pillars of Wisdom, over the Great Flood. Anagogically, it shows eternity triumphing over time. ${ }^{10}$

These statements, from James as commissioning novelist, Coburn, himself, and Coburn's best critic, sum up a compelling understanding of Coburn, at least in the period of his London work. Yet, it requires a dedicated adherent of a symbolist aesthetic and the synechdochal claims upon which it rests, to ignore the literal or discursive level of content in Coburn's photographs. Content is a dimension that photography records more effectively than any other medium (with the exception of the movies), even when techniques, such as the soft-focus and telephoto lens used by Coburn at that time, increase opacity and promote pictorial flatness. Coburn complained that 'the camera if left to its own devices will simply impart local information to the exclusion of everything else' ${ }^{11}$ Photography's other defining characteristics are the simultaneous capturing of a moment in time and a point of view in space, and the implied world continuing 
beyond the frame. Later, we can acknowledge that these, too, prove to be a check upon the dominant symbolism of Coburn's London photographs and, therefore, are factors in assessing how cities can be known.

St Paul's from the River is as perfectly composed a photograph as one might imagine, but composition works both ways, and can highlight, as well as relegate, the literal, discursive content. The flatness that derives particularly from the positioning of the dome, as though it sits on the bridge, creates compositional unity but also provokes speculation about what possible frame could contain potentially discordant elements. The river strikes us immediately as a shimmering image. But, then, a cluster of boats moored near Waterloo Bridge is associated compositionally, by means of two boats in mid-stream, with the river. The river is thereby re-animated, though less as a 'liquid surface', in which movement is somehow not to or from anywhere, but, as the Thames, flowing eastwards to the sea as London's greatest trade route and source of financial liquidity. Similarly, the spires of St. Paul's and other churches stand out from the mass of undifferentiated buildings to reach towards the halo of light in a lowering sky. They overlook mere trade on the river. Henry James had much to say in The American Scene about the skyscrapers of New York which, as 'monsters of the mere market' dominated, from above, the spire of Trinity Church on Broadway. ${ }^{12}$ In Coburn's remarkable photographs of London, an equally significant relationship between religion and trade is proposed by means of a compositional link in a flat plane that seeks to transcend the historically contingent sphere. It is not exactly a reversal of James's regret on behalf of Trinity Church, but St. Paul's endorses the material activities below by appearing to rise from the bridge, reminiscent of the shops and merchants' premises of Florence's Ponte Vecchio.

A 'liquid surface' is, again, prominent, even central, in Coburn's closeup view of the river, Waterloo Bridge (1906). ${ }^{13}$ It separates the foreground from the background, where we have a glimpse of buildings on the far bank of the river. Yet, the relatively small patch of light, far from 'overpassing' -- as Coburn 
would have it -- the day-to-day details of work, is circumscribed by what the photograph also tells us of the past work of building the bridge, and the present work on the river. Taken almost at river level, Waterloo Bridge depicts a river of trade, with the prow of a working boat jutting out from the bottom left corner, smaller boats visible under the arch of the bridge, and the brickwork of the bridge. This is an alternative to Coburn's London Bridge (1905), in which the superstructure is pre-eminent, with its business end and physical infrastructure hidden. Waterloo Bridge is structurally similar to The Tower Bridge (c. 1906), in which the working aspects also occupy most of the photograph, but compete, for impact, with the familiar imposing bridge structure in the background. ${ }^{14}$

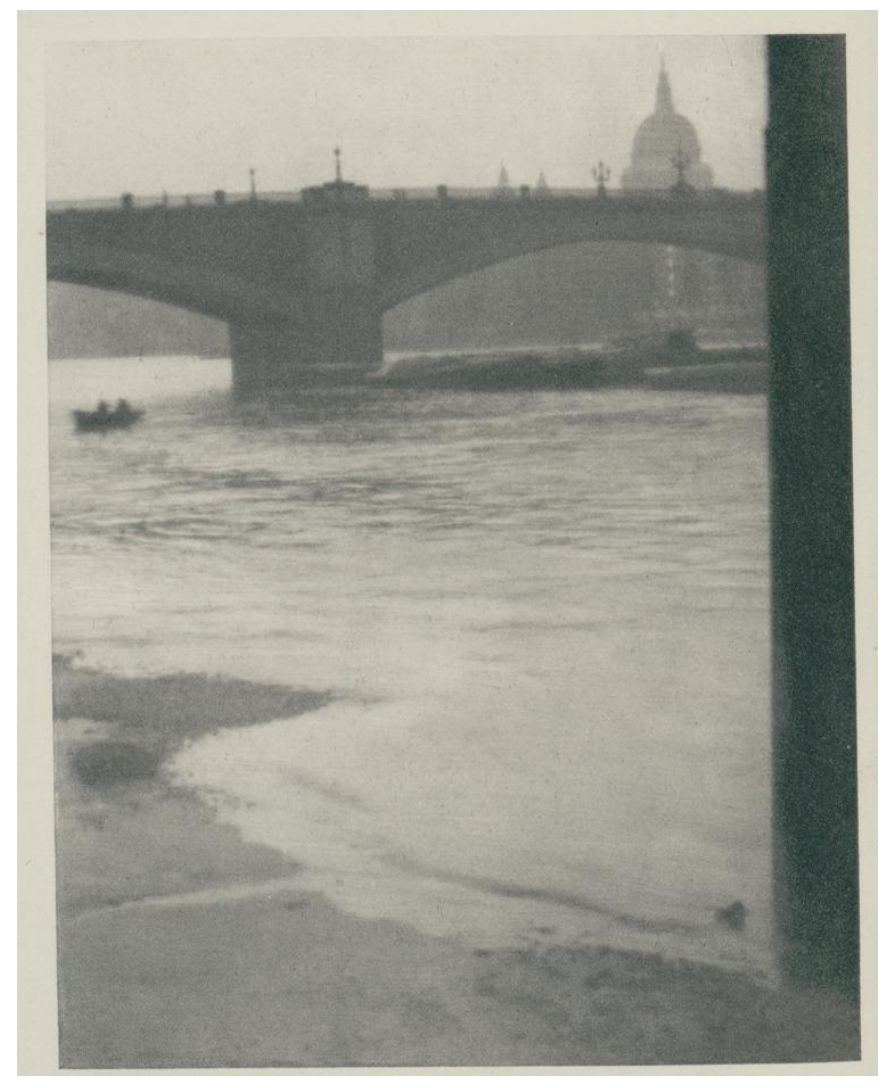

Figure 1: Alvin Langdon Coburn, The Dome of St Paul's, frontispiece to The Princess Casamassima, The Novels and Tales of Henry James, V, Book Collection, Harry Ransom Humanities Research Center, The University of Texas at Austin.

The banks of the Thames feature in a number of Coburn's photographs, in spite of the ostensible interest in more elevated cultural icons along the river. 
In The Dome of St. Paul's (see figure 1), Coburn catches the current running fast under the old Southwark Bridge, the light on the water, and the silhouette of the cathedral on the far side of the bridge. St. Paul's may be distant, and vague, but its height and cultural resonance ensure prominence, not least in the title of the photograph. However, the foreground of The Dome of St. Paul's is occupied by the muddy edge of the Thames, lapped by small waves. On the right-hand side of the photograph, the upright of a riverside structure (probably Cannon Street Railway Bridge), figures as an internal part-frame. It serves to draw the eye down from the sphere of St. Paul's to the foreground. This muddy space, which, twice a day, disappears with the flood tide, is also the point of view from which the photograph is taken: the south bank of the Thames, at low tide. The threshold between land and water is vague. From this unprepossessing foreground, the photograph takes on a subtle difference from those in which shimmering light and the mystery of Impressionist-like distance from the object are invariably dominant.

Jean-Paul Sartre's comments on a related phenomenon, slime, pinpoint two contrasting characteristics of the river conveyed by Coburn in The Dome of St. Paul's. Sartre's description, 'the permanence within change that water has', is akin to what Coburn is getting at in his phrase 'liquid surface'. But, then, Sartre adds, there is the 'aberrant fluid' that is slime, 'the agony of water'. He designates slime an 'antivalue', and there is something of this in the mud that Coburn portrays, though the idea of mud as a boundary between states is more pertinent. This boundary comes and goes, but does so within the city, rather than at the rural edge of London marked by the old house in E. M. Forster's novel of the same period. In The Dome of St. Paul's there is a rivulet coming in from the left and crossing the mud, an outlet for water or sewage from the city, one would think, and a tiny instance of the circulation of the city's water; just as the Thames was, even in the great age of the railways, a major instance of the circulation of trade. A common stage in city-formation has been the incorporation 
within the city's systems of locations and their associated activities that were once firmly consigned to areas outside of the city walls: cemeteries, wastedisposal, even some markets. ${ }^{15}$ The mud-bank between high and low tide is an intriguing sign of this process of absorption, being both centrally inside the city and at an edge that appears and disappears; and, to rely on Sartre once more, is 'already almost a solid permanence', a 'sticky thickness in its liquidity'. ${ }^{16}$ In one of his most famous London photographs, The Embankment (1906), the tide is higher, and the edge has become more solid: a curve of streetlamps and trees on the embankment, with, above it, once again, the dome of St. Paul's, and, below it, the river. Not all of the lamps can be reflected in the river, however, because the water only partially covers the mud, an ambiguous sign of what is and is not the city.

At the time when Coburn was photographing St. Paul's from the edge of the Thames -- as a frontispiece to James's one attempt, twenty years earlier, at a sustained treatment of the urban working class in The Princess Casamassima -- these muddy edges would still have been the location for small boats to be launched and moored, and for a scavenging trade in goods, and also in people who lacked the comfort of James, in his resident-alien category. The muddy edges are the sphere of the everyday, and of the river as a working space and, therefore, in terminology given resonance by Kevin Lynch in The Image of the City, a place for some people, yet a place that was not always in sight, and hidden from the official iconology of the city. For all their preoccupation with the famous sights of London, many of Coburn's photographs keep the all-but-hidden in view. ${ }^{17}$

The composition of Wapping (c. 1905) ${ }^{18}$ shows the Japanese influence on Coburn in flattening the plane of the photograph, yet also tells us that James and Coburn's quest to find, in James's expression, the 'spirit of the great city' has to acknowledge the co-existence of work. Evidently, work has taken over both sides of the river. On the nearside are the posts of a dock, the sails and rigging 
of a moored schooner, and a small boat and oarsman just offshore. There are no famous buildings in sight, and even the high-street of Wapping, itself, is replaced, on the far bank, by the Thames-side warehouses, 'these rigidly unfeatured edifices'. These are James's words when describing a day-trip by boat from Westminster to Greenwich. James continues, blithely crossing the border between form and contingent historical circumstances, between the city and its vast hinterland:

all this sordid detail reminds me of nothing less than the wealth and power of the British empire at large; so that a kind of metaphysical magnificence hovers over the scene, and supplies what may be literally wanting. ${ }^{19}$

In a few of Coburn's photographs, and in James's occasional, quite startling statements, such as the one above, it is the invisible totality, alone, that finally makes sense of the contingent details. For all his growing assurance as a writer, apparent in his subtle shifts of time and place and a facility with telling phrases to sum up a city, James's search for mastery over the city leads him to opt, first, for a conventional, topical source of meaning for citizens of London in the late nineteenth-century -- 'the British empire at large' - before, then, settling for the compensations of a 'metaphysical magnificence'. In Coburn's case, photography offers a quite specific resistance to the metaphysics that, if anything, he embraced more whole-heartedly than James. After the ability to record detail, the second defining characteristic of photography is that a photograph signifies the moment in which an image was captured, and the invisible point of view of the photographer. In Parliament from the River (c. 1906) Coburn leaves the point of view from the muddy edge of the river in The Dome of St. Paul's, and assumes a position behind the oarsman, as he, on his barge mid-stream, occupying the foreground and in focus, looks across the bow at the locus of political power and authority embodied in buildings. Mistiness, here, signifies, in some measure, the inaccessibility of power that is nevertheless present and inescapable. In spite of 
the distance across the river, Coburn's lens captures the gothic architecture of Parliament, thereby evoking religion, less to subsume politics into a greater venture and more to suggest a sustaining alliance between church and state. The same alliance is present in Westminster Abbey (1905), taken from the street corner of Victoria Embankment and Westminster Bridge, looking over Parliament's Old Palace Yard to St. Margaret's Church, and then the Abbey. ${ }^{20}$ Coburn's London was published in two editions within a few years of each other. They have quite different introductory essays that bear upon the questions of how the sheer 'thereness' of objects and people in a photograph can be assimilated into the desired aesthetic whole; and how, in James's terminology, 'type' and 'specimen' may relate to each other. The text of London: A Book of Aspects (1909) by the Symbolist poet and critic, Arthur Symons, became the Introduction to the very limited edition of London (1914). It is a piece of literary Impressionism, full of images of London that accord with the aspects of the city favoured by Coburn and James. Thus:

If the Thames is the soul of London, and if the parks are its eyes, surely Trafalgar Square may be reckoned its heart. There is no hour of day or night when it is not admirable, but for my part I prefer the evening, just as it grows dusk, after a day of heavy rain. ${ }^{21}$

Throughout, Symons is more comfortable with the symbolic potential of London's streets than with the details, which perturb him greatly. Yet his backward-looking overview, when read alongside Coburn's photographs, credits the totality, whether imagined as a body or as a metaphysical entity, with more authority than can be justified when the mimetic detail of the photographs, as well as their formal points of view, are contextualised historically. For Hilaire Belloc, in the rival Introduction to Coburn's London (1909):

The prime element in the structure of the town from its very beginnings has been its combination of commercial port and national capital. ... 
London, in a word, was in every way called to be a meeting-place, and especially a meeting place of commerce. ${ }^{22}$

Understandably, Coburn was amazed that his photographs were apparently ignored, especially as Belloc apparently thought highly of them. Still, we can take Belloc's concern with trade, politics, religion, and class, and specifically with the systemic, circulatory aspect of London's trade associated with the river, as encouraging a fresh look at Coburn's photographs. Circulation extends far beyond the Thames, however.

In the 'Preface' to In the Cage James risks the symbolic aesthetic that he had set out in 'London' along a narrative line; that is to say, having subtly associated aesthetics and metaphysics in his writings about cities, almost presenting them as spaces for the refinement of a style, he confidently descends the social scale and enters a mundane world, one of shabby respectability as characters come to populate his narrative:

The postal-telegraph office in general, and above all the small local office of one's immediate neighbourhood, scene of the transaction of so much of one's daily business, haunt of one's needs and one's duties ... had ever had, to my sense, so much of London to give out, so much of its huge perpetual story to tell, that any momentary wait there seemed to take place in a strong social draught, the stiffest breeze of the human comedy. ${ }^{23}$

James was far from metaphysical in his instructions to Coburn, dispatching him to a specific, if generic and nondescript, London sight, one with some interesting ramifications:

There will be then another thing that I haven't mentioned, for 'In the Cage': a London corner, if possible, with a grocer's shop containing a postal-telegraph office. ... Look for grocer's shops with post-offices inside. $^{24}$ 
James's reliance on letters and telegrams would have made him broadly aware of the status of the General Post Office, if not necessarily aware that an 1867 Act of Parliament had given it almost a monopoly over communications. Importantly, he positions his telegraphist at the nexus of commerce and communications in Cocker's:

This transparent screen fenced out or fenced in, according to the side of the narrow counter on which the human lot was cast, the duskiest corner of a shop pervaded ... at all times by the presence of hams, cheese, dried fish, soap, varnish, paraffin, and other solids and fluids that she came to know perfectly by their smells without consenting to know them by their names.

The telegraphist, as a 'public servant', however, 'obscure', perceives herself to be above Mr Mudge, her former colleague and fiancé, whose unwavering and, finally, fulfilled, expectation that he will marry her is founded on his own narrative. In descending the social ladder by transferring from the Mayfair post-office/grocer's shop to the 'much lower neighbourhood' of Chalk Farm, he moves up the economic ladder by his promotion 'to a more commanding position', and because his interest is decidedly on the commercial side of the 'transparent screen' that, from his point of view, fences in the public servant. ${ }^{25}$ Mr Mudge, at least, savours the names of the commodities, and, we can reasonably assume, their differentiating brand-names, as well. Whatever else it is, In the Cage is a story of commodities, a point that is underlined by the absence of people and even of a door to the shop in Coburn's photograph. 


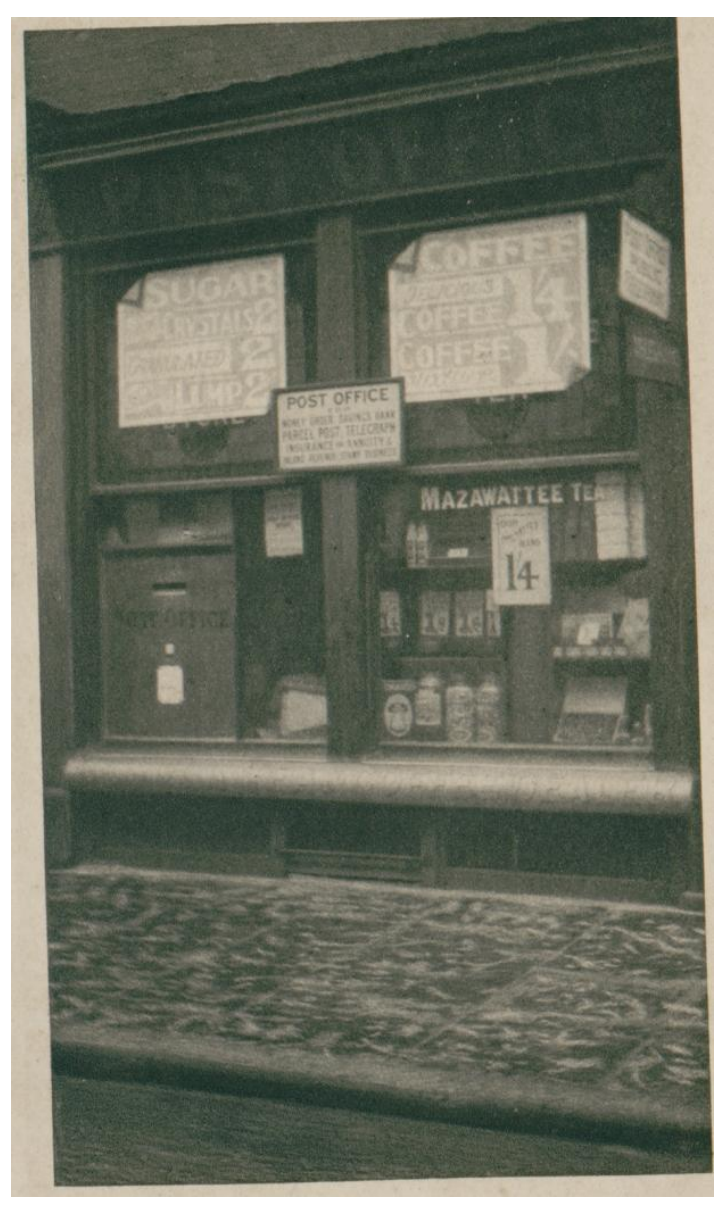

Figure 2: Alvin Langdon Coburn, The Cage, frontispiece to In the Cage, The Novels and Tales of Henry James, XI, Book Collection, Harry Ransom Humanities Research Center, The University of Texas at Austin.

Among Coburn's photographs of cities, the frontispiece of the volume of The New York Edition containing In the Cage is unusual in its archival detail, and for the kind of clarity that his pictorialist techniques of the time 'brushed' aside, much as Impressionist painters had been doing for three decades. The Cage (c. 1906), as it is captioned (see figure 2) reveals the interconnections of class, trade and the city, as mediated through the postal service. These interconnections, it can be argued, constituted London, not through synechdochal relations between part and whole, but through a structural logic of exchange. This logic is revealed in Coburn's photograph of commodities in a shop window, and also through Joseph Pennell's images of London's transportation. The order 
of priority in Coburn's photograph is a matter of point of view. The photograph takes in only the capitalized, engraved words, 'Post Office', along the top of the shop-front, and, therefore, it is not apparent whether there is more shop signage, around the corner, devoted to the grocery business. A rectangular white sign details the Post Office's services, including 'Parcel Post Telegraph' and a savings bank facility, while the post-box itself, set into the wall of the shop, and occupying one of the four visible window spaces, supports the Post Office's precedence. However, the other three window spaces are insistently commercial, encouraging spending rather than saving. In the top two windows, there are posters advertising the cost of sugar and coffee. In the bottom-right window, are containers for tea, sweets and other goods. Commodities are also depicted in the other, more up-market, London shop-window photographed by Coburn, under James's guidance, as the frontispiece for The Golden Bowl, though the paintings and antique plates in The Curiosity Shop lack prices, and the display is more muted.

Ostensibly, the post-office function drives James's narrative, and moves the telegraphist beyond the daily routine of the shop and into the wider city. As she discerns the intricacies of the aristocratic affair at the centre of the plot, reference points in the city become less tangible, pronouns multiply and narrative turns back on, and around, itself before, indeterminately, proceeding. It becomes more and more of a 'late' tale by Henry James, in which the layers of self-consciousness leave a margin, from which 'a London corner' may reveal 'so much of London ... so much of its huge perpetual story'. But this is a story in which epistemological ambiguities are more embedded in the changing dynamic of London's economic and social world than its style and narrative structure might suggest. This dynamic is visually set out in Coburn's photograph, but with much greater emphasis on commodity fetishism than in James, for all his efforts to be contemporary. In the 'grocer's shop containing a postal-telegraph office', trade has an eye for the main chance, as the self-made man, Mr Mudge, 
recognises. 'The exuberance of the aristocracy was the advantage of trade', he observes, 'and everything was knit together in a richness of pattern that it was good to follow with one's finger-tips'. 'The more flirtations' [within the aristocracy and conducted through the postal service], 'the more cheese and pickles'. ${ }^{26}$

For all the plot's attention to aristocratic indiscretions and the telegraphist's role, the established social and economic power structure is hardly immune to trade, and, arguably, this proves to be a greater drama. Much the same may be said of the barrier between the public and commercial spheres, as manifested by the interior disposition of Cocker's, and the spatial organisation of the window that Coburn photographed. The photograph appears to be quite rigidly structured around horizontal and vertical bands, including the almost abstract foreground. Yet this mini-archive of consumption points to an invisible logic of exchange that mixes things up, not least the separation between appearance and reality. In the top two of the four windows, the sugar and coffee advertising posters have been pasted over what appear to be more permanent window signs, this superimposition signalling a need for speedier communication with potential customers in order to maximize sales. That the top left corners of both posters are turning down anticipates the next advertisement. The items in the bottom right window are also presumably inter-changeable. In the Cage and The Cage are of the same world that Thorstein Veblen describes in The Theory of the Leisure Class (1899), one in which a production economy is distorted by exchange-value. The proliferating mediations -- in James's words, 'needs', 'duties', 'labours', 'rewards' and 'disappointments' -- are all given economic value in the 'mysterious character of the commodity-form', as Marx puts it. ${ }^{27}$ For $\mathrm{Mr}$ Mudge, these mediations are not mere illusions. They connect aristocratic affairs with grocery sales, and, in-glorious as they sound, are very much a part of 'that deepest abyss of all the wonderments that break out for the student of great cities'. Importantly, class and trade, society and economy, are put into 
relationships by the public postal network, a system that crosses the city's limits but also the nation's.

The global reach of the commercial world is most prominently represented in Coburn's frontispiece photograph by a sign for Mazawattee Tea painted onto, rather than engraved into, the glass of the bottom right window. There is a typicality about this detail of a brand that is of a different, more lowly kind, than applies to James's 'Specimens', which evoke 'Types'. Nevertheless, a brand name resonates, too, as Alan Davies reports:

Most of Densham \& Sons business was now selling tea in bulk to local grocers, which was then blended by the grocer for the retail trade. ... It was John Lane Densham who was instrumental in persuading his brothers that the company needed a romantic and eye-catching name and, after a day spent in the Guildhall library, chose the name Mazawattee. ${ }^{28}$

The brand-name was registered in 1887, and derived, according to Davies, from 'mazathe', Hindi for luscious, being combined with 'wattee', Ceylonese for garden, to create an exotic image for an urban market. London was the capital of trade, and the company was vigorous in its brand-differentiation through the $1890 \mathrm{~s}$. It is not surprising, then, to find an advertisement for Mazawattee Tea in Coburn's shop window, though, by the time of his photograph, the price of tea had risen to include higher taxes to cover the heavy cost of the Boer War (1899-1902). Thus, the exchange between London and Ceylon, passing through the East India Docks, which provoke in James, in 'London at Midsummer', the 'imaginative thrill' of Empire, was being diverted to assist in reparations and the post-war restructuring in South Africa. ${ }^{29}$ The significance of this detail in Coburn's photograph expands, but not because the part symbolises a harmonious totality. Part meets whole through the evocation of trade routes between far-flung parts of the Empire and London. When rejecting the 'miniature cameras' of the Kodak era, Coburn stated 'I like to compose my pictures to the edge ${ }^{\prime 30}$. Here, Coburn's photograph follows trade lines to the edge. 
An observation, by Stanley Cavell in The World Viewed: Reflections on the Ontology of Film, calls up the third defining aspect of photography as a medium, beyond that of the recording of details and of the moment in which, and the location from which, a photograph was taken:

What happens in a photograph is that it comes to an end. A photograph is cropped, not necessarily by a paper cutter or by masking but by the camera itself. ... The camera, being finite, crops a portion from an indefinitely larger field. ... When a photograph is cropped, the rest of the world is cut out. The implied presence of the rest of the world, and its explicit rejection, are as essential in the experience of a photograph as what it explicitly presents. ${ }^{31}$

A photograph sharpens the sense of a threshold, which, as it encloses a scene, in the case of Coburn's The Cage, discloses a wider world, one to which even $\mathrm{Mr}$ Mudge is connected, in his grocer's career in an obscure northern part of the city. Details and lines in a photograph are never that alone, because comprehension of an image within its own frame cannot fully equate to comprehensiveness of knowledge.

Details make sense in their signifying relationships. Beyond the edge of a photograph, lines imply direction or extension, including the lattice-work of lines in the foreground and the indistinct ones in the background in Wapping. These lines in Coburn's city photographs advise us that bridges, machinery, buildings, streets, rivers, and - most inclusively, if least dramatically commodities can only ever be partially meaningful in themselves, and need 'the rest of the world'. Labour in distant parts of the empire is needed to produce tea, and labour is needed in the centre of the empire to retail it. Probably the most well-known evocation of the trading lines of Empire is in Heart of Darkness (1902) by Joseph Conrad, whom Coburn photographed in 1916, for More Men of Mark (1922), as he had photographed James in 1905 for Men of Mark (1913). The story begins on the lower reaches of the Thames, 'like the beginning of an 
interminable waterway', linking, Conrad continues, 'the biggest, and the greatest, town on earth' to, in James's words 'the wealth and power of the British empire at large'.$^{32}$ This context supplies a compelling meaning to the misty outlines of warehouses and the abstracted parts of river-side machinery that otherwise flatten Coburn's images. It is not that reality, in Coburn's photographs, is illusory, or even inverted, as Marx polemically has it in his famous camera obscura analogy in The German Ideology (1845-47). If the meaning is less than clear, then, like the commodities in the post-office/grocery window, this is, in Étienne Balibar's explication of Marx, 'the way in which reality (a certain form or social structure) cannot but appear'.33

IV

In contrast to the close collaboration that he developed with Coburn, James seemed little bothered by what Joseph Pennell would visually add to 'London' when it was published in The Century Magazine in 1888. He invited Pennell to 'follow your own fancy. ... do your own London, and it will be sufficiently mine'. ${ }^{34}$ Yet, with all but two of the drawings devoted to scenes of travel by rail, road and river to, from and across the metropolis, Pennell, in a different visual medium from Coburn, also speculates on the idea of a threshold to the city, and the extent to which London may be picturable in all its relations.

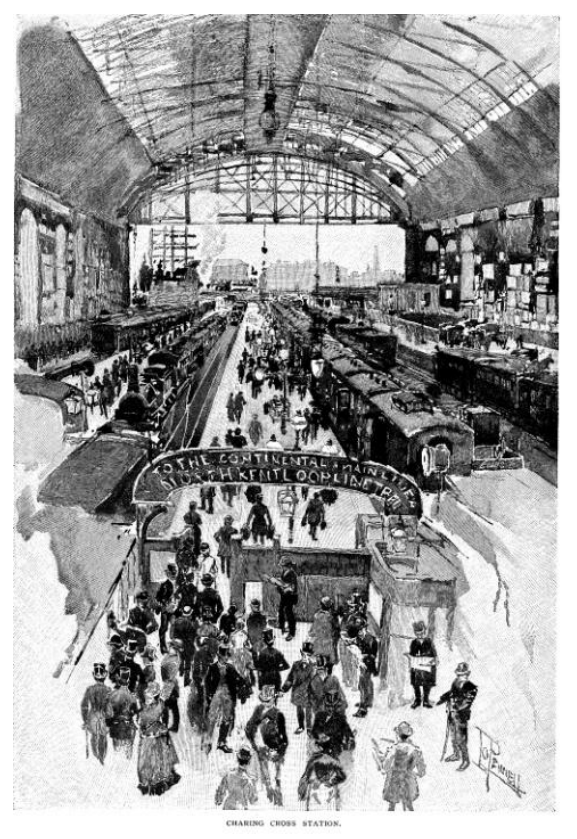


Figure 3: Joseph Pennell, Charing Cross Station, from Henry James, 'London', The Century Magazine, 37 (December 1888).

Pennell's first drawing is of Charing Cross Station (see figure 3), not Euston, where James had arrived in 1869 , and is almost exaggeratedly oriented towards themes of arrival and departure, and people on the move. Pennell's bid for pictorial unity is at the other end of the spectrum from Coburn's and James's Modernist strategies. One-point perspective straightforwardly connects foreground and background, whereas Coburn's pictorial inclinations seek to flatten such coordinates. And, as we have remarked, James's peregrinations and constant qualifications of his own narrative of arrival in London (having already arrived, as it were), subject narrative to the irony that becomes possible when a secure citizen of the city views his earlier, arriving self. Pennell adopts a less subtle approach. From a position at the same height as the skyline, which is dimly visible through the awning of the Charing Cross train shed, perspective is enforced by the receding platforms and tracks, the latter occupied by arriving and departing trains, with passengers streaming through the ticket barrier on to the platform, under a sign: 'To the Continental Main Line [and] North Kent Loop Line Train'. However, as in other drawings for 'London', such as Bow Bells, Cheapside, Piccadilly and In the Underground, pictorial unity, sought through use of traditional perspective, is combined with a decided anecdotal quality. ${ }^{35}$ Travelers of different class and gender are picked out and take on character, much as the letters on the platform sign are self-consciously drawn and, uneven and irregular, are individualized. Potential stories are inaugurated by men's hats: from top hats, sometimes matched by morning dress and usually paired with a walking stick as accessory, through trilby- and bowler-hats, to the cap of the ticket-inspector at the barrier. Newspapers, in the hands of men, wearing a range of hats, suggest the public context of other stories, and a differentiation of news according to class interest. 
The details of travellers on the concourse in Charing Cross Station (1888) or of pedestrians, carriage-born citizens and those struggling with barrows depicted in Bow Bells, Cheapside do not coalesce, as they do in Pennell's later more Modernist etchings. By 1905 and the reprinting of 'London' in English Hours, Pennell had fully adopted an Impressionistic style and his entirely new set of drawings were part of a reaction to the clarity of detail that photographic technology could deliver. Yet, the localised discrimination possible in drawing and its associated technologies is a reason to hesitate in the face of visual Modernism's tempting offer of pictorial unity. For the frontispieces to the New York Edition, James asked Coburn to omit people, and while there are a few, the approach is far removed from the anecdotal.

It could have been London's lack of a surrounding city wall, such as James was pleased to encounter in Chester, which he visited in 1869, that led him to describe the approaching 'general immensity' of London as a network: 'the miles of housetops and viaducts, the complication of junctions and signals through which we made our way to the station'. While not troubled by metaphysical presences and absences, Pennell's drawings share with James's writings an awareness that places of arrival are also places of departure; and with that awareness, comes an interest in what London's identity might be, as the city of meetings and transactions (what James calls 'our reciprocities and activities') and of physical journeys and communications. ${ }^{36}$ Pennell contributes insights into the infrastructure of London as a crossroads, one that faces the rest of the nation, including, to the north-west Liverpool and, from there, the Atlantic world, and, to the south, the Continent and the Empire beyond. To be at Charing Cross, in Pennell's drawing, is to register a curious form of motion: headed for somewhere else, propelled by an exaggerated one-point visual perspective; distracted by anecdotal detail; and at a threshold of somewhere different that is yet part of the same railway system. Pennell pursues this last conjunction of sameness and difference in his choice of succeeding images. A Cab Stand shows 
a road under Charing Cross Railway Station; that is, an intersection between rail and road travel. Somerset House, From Charing Cross takes us above the rail bridge, and depicts the tracks coming out of the station crossing, first, the horsedrawn traffic on the Embankment and then the Thames, with a steamer moored almost under the bridge. Other drawings are of barges moored at Limehouse and across from the Tower of London at flood tide.

When, early in 1912, Pennell had the opportunity to draw the Panama Canal under construction, he worried that he would get to Panama too late: 'the work [would be] finished and ... there would be nothing to see'. He was fascinated by what could be seen, during construction projects, of the infrastructure that, in the case of the Canal, would 'be beneath the waters on one side and filled in with earth on the other'. His drawings of the London Underground, the great construction project in the years after 1884, when he moved to the city, are not of the invisible workings, but of the appearance of what has been hidden, 'filled in with earth'. ${ }^{37}$

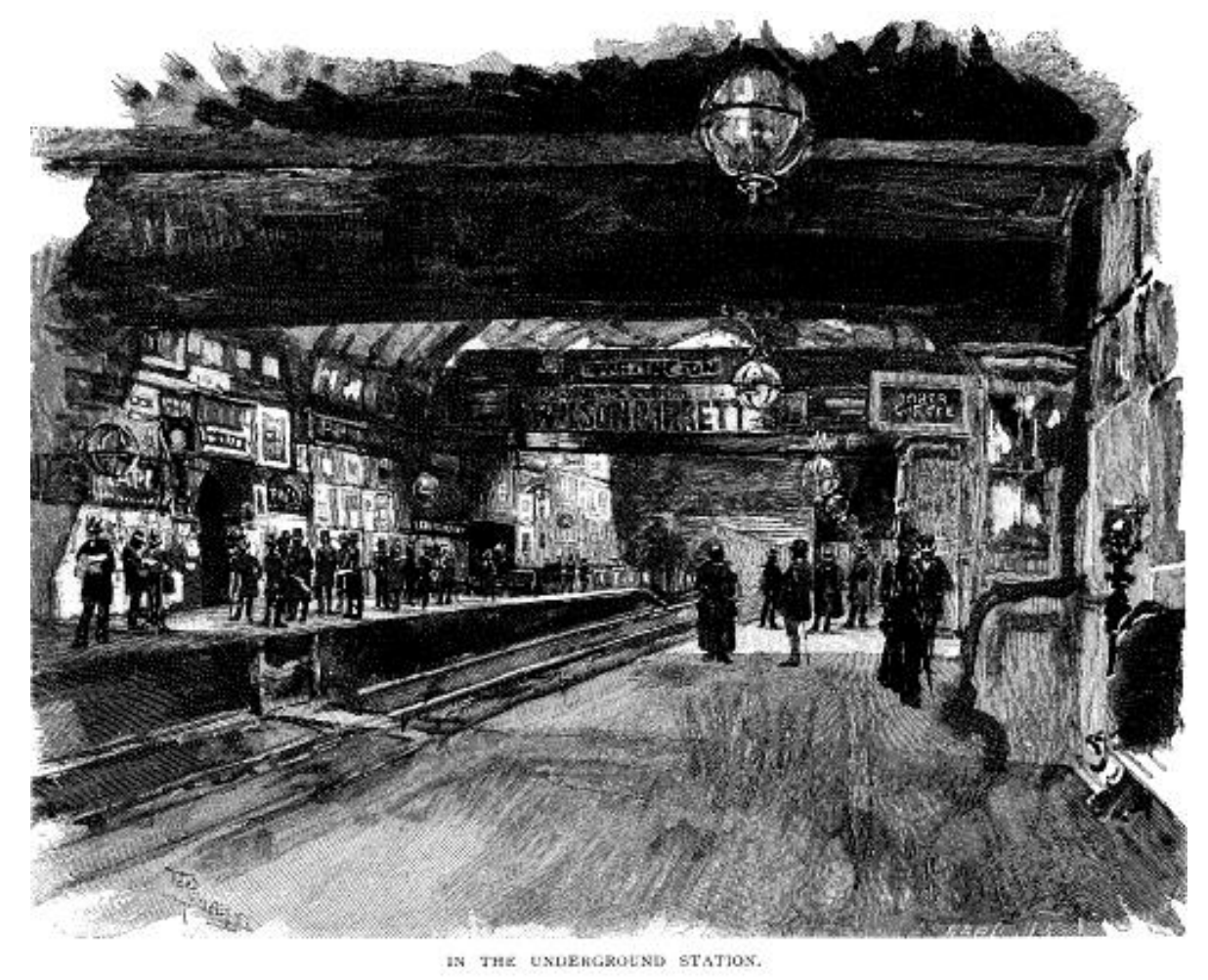

Figure 4: Joseph Pennell, In the Underground Station, from Henry James, 'London', The Century Magazine, 37 (December 1888). 
In the Underground Station (1888) (see figure 4) is the third drawing in 'London', and follows on from Charing Cross Station and A Cab Stand. Pennell shows passengers on two facing platforms of a station on the Inner Circle Line, as the modern-day Circle Line was known. Anecdote, again, distracts attention away from the tracks to 'society', meeting on the spacious platforms. The location is of more interest in this case, though. The station name is indeterminately reproduced as a sign over the tracks, to the extent that while the letters designate that it is probably Paddington underground station, there is enough of an overlap between the ten letters to suggest an amalgam of 'Farringdon' and 'Paddington'.

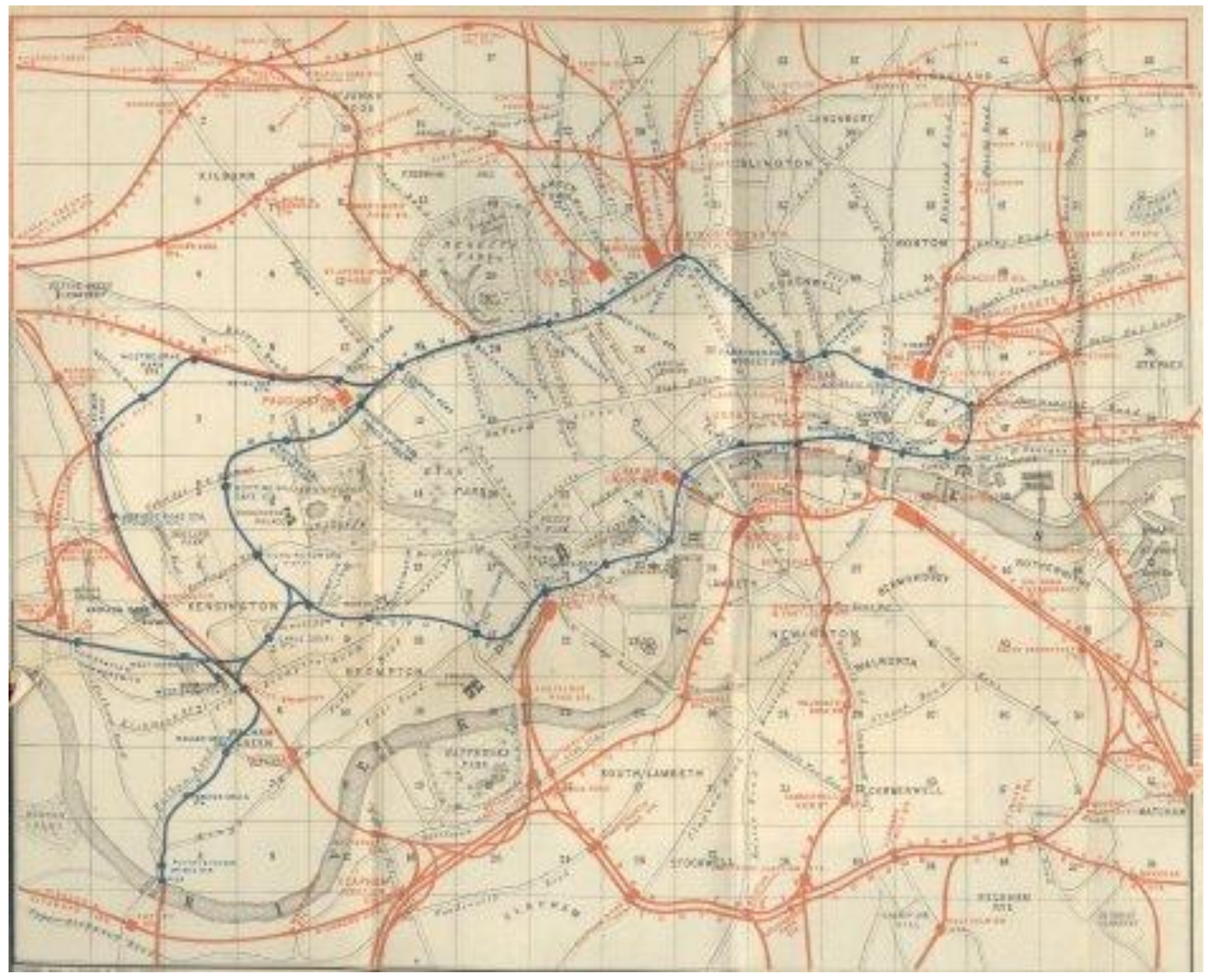

Figure 5: Anon., Railway Plan of London and its Suburbs (1889), from Clive Billson, A History of the London Tube Maps, http://holopaw.me.uk (last viewed $7^{\text {th }}$ June, 2009). 
The stretch of line between these stations, dating from the opening ceremony on $9^{\text {th }}$ January, 1863 , is the oldest in what became the Underground. In 1888 it was the busiest stretch of line, with approaching five hundred trains per day. Moreover, at both Paddington and Farringdon there were intersections with the over-ground rail system. The Great Western, and then the Great Northern, ran trains into Paddington and then on through to Farringdon, and, in so doing, projected a notion of structure as network (see figure 5). When the Inner Circle Line was completed it created an inner network within the national network, rather than being, in Christian Wolmar's view, 'little more than an underground tunnel below London which happened to serve several local stations ${ }^{\prime} .^{38}$ Using the Inner Circle as a point of comparison for the roadway laid out as part of John Nash's adjoining Regent's Park, Arthur Symons misses the point. 'And there is the perplexing inner circle', he grumbles, 'which is as difficult to get in or out of as its lamentable namesake underground'. ${ }^{39}$ The point is that in economic as well as structural terms, the Inner Circle Line envisages a functional logic of circulation, rather than a totality, an insight that became institutionalised in 1931, when Harry Beck's structural map gained favour over geographical maps of London Underground. In funding terms, too, the private sector built the lines, and then the Metropolitan and District companies had to construct the operating system -- in effect, the managing of time and space -without any central transport authority, though Farringdon and Paddington were both promoted as potential head-quarters. This paradoxical notion of an identifiable, named entity which yet had permeable boundaries, and which could, somehow, be represented, applies equally to the metropolis as to the 'Underground'. Thus, Farringdon and Paddington exemplified, for Pennell, the busy intersection that, on a vast scale, made up London, which, in turn, was inextricably connected with somewhere else. Appropriately, to the east, the Inner Circle Line served the City of London which was at the financial centre of an 
empire. These are common enough insights now but were hard-earned in the late nineteenth-century.

During this period in his career, when he felt less challenged by photography's ability to reproduce details, Pennell exploited drawing's ability to capture a dramatic but peculiar form of urban content, namely physical signs that, by definition, signified something else. In Sunset in Oxford Street the skyline of five-storey buildings and church steeples is over-topped by a large sign on a framework of posts. The words are indistinct, as they are in Piccadilly and Bow Bells, Cheapside, where men are converted into portable signs by the billboards they carry. It is possible to make out, on one of the billboards in each drawing, the word 'London', and Pennell jokingly qualifies and personalises the citydesignation in Bow Bells, Cheapside as 'Pennell London 1888'. With that exception, the proliferation of signs and the instances of clocks in a number of the drawings, signify an impersonal city, one in which people are unknown to each other and must, therefore, be informed, directed and encouraged to buy goods and services. The station walls in In the Underground Station (see figure 4) are covered with signs, a mixture of directional or informational signs and advertising. The easiest one to make out is above the station's less-than-distinct name, and advertises 'Wilson Barrett'. He was an actor, playwright and theatre manager whose career had a late revival with a few successful melodramas on the London stage in the 1880s. All of the Underground companies maximised the opportunity to advertise their own services, but, also, the services, entertainments and products to which their tracks gave easier access. Shops and theatres, in return, consistently mentioned the proximity of an Underground station in the advertisements they took out in newspapers, thereby helping to create a circuit of signs that brought together transportation and trade, each with its sub-systems of communication.

In The Philosophy of Marx Étienne Balibar defends the mere appearances of social life against metaphysics, whether of the transcendental or 
materialist kind, and explains why even the superficial detail of a brand name, should not be overlooked:

Now fetishism is not a subjective phenomenon or a false perception of reality, as an optical illusion or a superstitious belief would be. It constitutes, rather, the way in which reality (a certain form or social structure) cannot but appear. ... To suppress the appearance would be to abolish social relations. ${ }^{40}$

It is precisely the point about capital that it does not have a reliable image, but that its pre-eminent site, the city, is full of prosaic signs, promising, advising, informing, and commanding. Malcolm Bull, in Seeing Things Hidden: Apocalypse, Vision and Totality, maintains that the period of modernity could, at most, witness 'the coming into hiding' of the unknown, as divergent elements in cities (classes, ethnic and racial groupings, religion, and trade) came to occupy the same space in time, and as it became more apparent in whose interest it was that capital should lack a clear representation. ${ }^{41}$

Coburn, James and, of the three of them, certainly Pennell did not subscribe to radical or reforming traditions in art or literature that sought to reveal economic and social fault-lines running through the city, upsetting, at some remove, versions of pictorial unity. Yet, we can interpret some of Coburn's photographs, however opaque, as displacing the image of capital and its institutions into the incidental and marginal but still just-about-visible details of a shop window, Thames-side machinery, and a muddy river bank. Similarly, Pennell's anecdotes and seemingly inconsequential, merely illustrative, interest in signs and in transportation networks interrupt any smooth passage from detail to totality. While, for his part, James's elaborate approach to a point of view in 'London', and his efforts, in some of his Prefaces to the London novels and stories as well as, more prosaically, in his instructions to Coburn, to reserve a margin for himself, reveal, in passing, how difficult it is to escape the complexity and indeterminacy of social relations in a great city. This was an insight James was 
happy to appropriate for his poetics in a less materialistic sense. But it is only by an inverted, and typically Modernist, understanding of alienation, allied to a dubious rhetorical play on use-value in the midst of the growing commodification of the telegraphist's world in In the Cage, that James can keep his distance: Admirable thus [the working class's] economic instinct; it is curious of nothing that it hasn't vital use for ... but somehow, after all, it gives no pause to the 'artist', to the morbid imagination. That rash, that idle faculty continues to abound in questions, and to supply answers to as many of them as possible; all of which makes a great occupation for idleness. ${ }^{42}$ Writing about another capital city, Prague, Jacques Derrida glosses some of the issues worked through in this essay. Quickly disposing of the historical definition of a city's limit -- 'a gate, walls, an administrative border' and so on -- he enquires, 'Is it enough to speak of the threshold to speak of the identity of a city?' His part-answer, that 'a city must remain open to knowing that it does not yet know what it will be', catches a sense of London in Coburn, James and Pennell, in spite of their stated models of representation. ${ }^{43}$ Their London was already facing up to the invisible communication systems and impersonal markets that would stretch and confuse any category of identity. Confident enough to entitle, between them, two books and a few essays with the name of the city, and to write and illustrate many more, in their efforts to describe, narrate or picture London, they became entangled with larger forces or, in nineteenth-century language, laws. 'As the great city makes everything', James casually remarks of London, in a comment that bears upon his own medium but more materially on the visual conditions for Coburn and Pennell, 'it makes its own system of weather and its own optical laws'. ${ }^{44}$ When these three citywatchers are alongside each other, whether in formal collaborations or not, the over-riding impression is of varying degrees of artistic authority bumping up against 'London [which] is only part of something else', in E. M. Forster's words, and 'London ... a strange thing', in Engels's. In seeking to name the larger totality 
and to fill the void, James turns to a rhetoric of excess. His memorable phrases

may be put together with the seemingly incidental details that cannot be

overlooked in some entrancing photographs by Coburn, and also with Pennell's

eye for detail and choice of locations that are, at once, inside the city and a part

of what is outside its boundaries. Together, they constitute some of the most

revealing representations of the hidden, but not unknowable, forces that make

and re-make a city.

\footnotetext{
${ }^{1}$ I should like to acknowledge the support of the Arts and Humanities Research Council. I would also like to thank Linda Briscoe Myers, Assistant Curator of Photography, Harry Ransom Center, University of Texas at Austin, Alan Griffiths at http://Luminous-lint, and Mark Katzman at www.photogravure.com for their advice on locating images; audiences at the Universities of Leicester, Nottingham, Oxford, Shanghai International Studies, and Tsinghua, Beijing, for their criticisms; and Jill Tallack for home-town knowledge.

2 Henry James, The Art of the Novel: Critical Prefaces, with an Introduction by Richard P. Blackmur (New York: Charles Scribner's Sons, 1937), p. 59.

${ }^{3}$ Their artistic collaborations have been thoughtfully and exhaustively examined by literature experts: Ralph Bogardus, Pictures and Texts: Henry James, A. L. Coburn, and New Ways of Seeing in Literary Culture (Ann Arbor: UMI Research Press, 1984); Wendy Graham, 'Pictures for Texts', The Henry James Review, 24, 1 (Winter 2003), pp. 1-26; David McWhirter (ed.), Henry James's New York Edition: The Construction of Authorship (Stanford: Stanford University Press, 1995), in particular Ira B. Nagel, 'Visual Culture: The Photo Frontispieces to the New York Edition', pp. 90-108; Carol Shloss, In Visible Light: Photography and the American Writer 1840-1940 (Oxford: Oxford University Press, 1987); and Viola Hopkins Winner, Henry James and the Visual Arts (Charlottesville: University Press of Virginia, 1970). Although these critics comment perceptively on James's affinity with visual aesthetics and spatial form, with very few exceptions, there has been less attention to James's, as well as Coburn's and Pennell's, insights into the city than one might have expected: a chapter in Mike Weaver's fine book, Alvin Langdon Coburn: Symbolist Photographer, 1882-1966: Beyond the Craft (New York: Aperture, 1986), though his over-riding interest is evident in his first sub-title; an astute article by Brigitte Bailey, who pauses, in her main concern with Henry James, to comment on one of Joseph Pennell's drawings: 'American Travel Writing and the Metropolis: James, London, and English Hours', American Literature, 67 (June 1995), pp. 201-32; and John Kinney's survey, Henry James and London: The City in his Fiction (New York: Peter Lang, 1991).

${ }^{4}$ E. M. Forster, Howards End (Harmondsworth, Middlesex: Penguin Books, 1941), p. 316. Friedrich Engels, The Condition of the Working Class in England, ed., Victor Kiernan (Harmondsworth, Middlesex: Penguin, 1987), p. 68.

${ }^{5}$ Henry James, 'London', The Century Magazine, 37 (December 1888), p. 219. James, The Art of the Novel, p. 155. See Joseph Pennell, 'Is Photography Among the Fine Arts?', Contemporary Review, 72 (1897), pp. 824-36.

6 James, 'London', pp. 219, 222.

7 Weaver, Alvin Langdon Coburn, p. 8.

8 James, quoted in Alvin Langdon Coburn, Alvin Langdon Coburn: Photographer (London: Faber and Faber, 1966), p. 52.
} 
${ }^{9}$ Coburn's St. Paul's from Ludgate Circus and St. Paul's from the River may be viewed by searching the collection of The Art of the Photogravure www.photogravure.com/ and accessing the on-line exhibition, Alvin Langdon Coburn: London at Luminous Lint: www.luminouslint.com/app/vexhibit/ PHOTOGRAPHER Alvin Langdon Coburn London 01/1/ $0 / 0 /$ (both sites last viewed $7^{\text {th }}$ June, 2009).

${ }^{10}$ Weaver, Alvin Langdon Coburn, p. 57. Earlier quotations from James and Coburn also in Weaver, Alvin Langdon Coburn, pp. 33 and 51. For insights into Coburn's contribution to a Whistler-inspired view of London, see William Sharpe, 'New York, Night, and Cultural Mythmaking: The Nocturne in Photography, 19001925', Smithsonian Studies in American Art, 2, 3, (Autumn, 1988), pp. 7-8.

${ }^{11}$ Coburn, Alvin Langdon Coburn: Photographer, p. 44.

12 James, The American Scene (Bloomington: Indiana University Press, 1968), pp. 78 and 80.

${ }^{13}$ See The Art of the Photogravure www.photogravure.com/ and Luminous Lint: www.luminouslint.com/app/vexhibit/ PHOTOGRAPHER Alvin Langdon Coburn London 01/1/ $0 / 0 /$ (last viewed $7^{\text {th }}$ June, 2009).

${ }^{14}$ For London Bridge and Tower Bridge, see Luminous Lint www.luminouslint.com/app/vexhibit/ PHOTOGRAPHER Alvin Langdon Coburn London 01/1/ $0 / 0 /$, (last viewed $7^{\text {th }}$ June, 2009).

${ }^{15}$ See Mark Kingwell, Concrete Reveries: Consciousness and the City (Toronto: Viking, 2008), pp. 219-22.

${ }^{16}$ Jean-Paul Sartre, Being and Nothingness: An Essay on Phenomenological Ontology, trans., Hazel E. Barnes (London: Routledge, 1991), pp. 607, 611. For a different interpretation of this section of Being and Nothingness, see Malcolm Bull, Seeing Things Hidden: Apocalypse, Vision and Totality (London: Verso, 1999), pp. 58-62.

${ }^{17}$ Kevin Lynch, The Image of the City (Cambridge, Massachusetts, The MIT Press, 1960), 119. Interestingly, James queried Coburn's inclusion of photographs of Paddington and Regent's Canals as an atypical urban sight when he was sent a copy of London (1909). For treatments of similarly over-looked places, see T. J. Clark, The Painting of Modern Life: Paris in the Art of Manet and his Followers (London: Thames and Hudson, 1985), pp. 23-41, and John R. Stilgoe, Metropolitan Corridor: Railroads and the American Scene (New Haven and London: Yale University Press, 1983).

${ }^{18}$ See The Art of the Photogravure www.photogravure.com/ and Luminous Lint: www.luminouslint.com/app/vexhibit/ PHOTOGRAPHER Alvin Langdon Coburn London 01/1/ $0 / 0 /$, (both last viewed $7^{\text {th }}$ June, 2009).

${ }_{19}$ James, 'London', p. 222. James, "London at Midsummer", Lippincott's Magazine, 20 (November), 1877, p. 608. For a more thorough analysis of James and Empire, see Bailey, 'American Travel Writing and the Metropolis: James, London, and English Hours', pp. 207-11.

${ }^{20} \mathrm{I}$ am grateful to Paddy Tipping, MP, for identifying the point of view in this photograph. See The Art of the Photogravure www.photogravure.com/ and Luminous Lint: www.luminous-

lint.com/app/vexhibit/ PHOTOGRAPHER Alvin Langdon Coburn London 01/1/ $0 / 0 /$ (both last viewed $7^{\text {th }}$ June, 2009).

${ }^{21}$ Arthur Symons, London: A Book of Aspects (New York: Garland, 1984), p. 6.

22 Hilaire Belloc, 'Introduction', Alvin Langdon Coburn, London (London:

Duckworth and Co., 1909), p. 10.

23 James, The Art of the Novel, p. 154.

${ }^{24}$ Henry James, Letters, Volume IV, 1895-1916, ed., Leon Edel, (Cambridge, Massachusetts: Belknap Press of Harvard University Press, 1984), p. 429. 
${ }^{25}$ James, In the Cage, in What Maisie Knew, In the Cage, The Pupil (London: Macmillan, 1922), pp. 325-26, 334, 326.

${ }^{26}$ James, In the Cage, p. 365.

27 Karl Marx, Capital, volume 1, trans., Ben Fowkes (Harmondsworth: Penguin, 1976), 165.

${ }^{28}$ Alan Davies, 'The Rich History of Mazawattee', Tea and Coffee Trade Journal 2, 1 (June 20), 2003, www.allbusiness.com/manufacturing/food-manufacturingfood-coffee-tea/570995-1.html, last viewed $7^{\text {th }}$ June, 2009.

${ }^{29}$ James, 'London at Midsummer', p. 608.

${ }^{30}$ Coburn, Alvin Langdon Coburn: Photographer, p. 46.

${ }^{31}$ Stanley Cavell, The World Viewed: Reflections on the Ontology of Film, enlarged edition (Cambridge, Massachusetts: Harvard University Press, 1979), p. 24.

32 Joseph Conrad, Heart of Darkness (New York: Dover, 1990), p. 1.

33 Étienne Balibar, The Philosophy of Marx, trans., Chris Turner (London: Verso, 1995), 60.

34 James, Letters, Volume 3, 1883-1895, ed., Leon Edel (Cambridge,

Massachusetts: Belknap Press of Harvard University Press, 1980), p. 218.

${ }^{35}$ For expanded discussions of anecdote, see John Fagg, 'Anecdote and the Painting of George Bellows', Journal of American Studies, 38, 3 (2004), pp. 47388, and Douglas Tallack, 'City Sights: Mapping and Representing New York', in Maria Balshaw and Liam Kennedy, eds., Urban Space and Representation (London: Pluto, 2000), p. 34, and New York Sights: Visualizing Old and New New York (Oxford: Berg, 2005), pp. 70-3 and 98.

36 James, 'London', pp. 219, 220 and 235.

37 Joseph Pennell, Joseph Pennell's Pictures of the Panama Canal: Reproductions of a Series of Lithographs made by him on the Isthmus of Panama, JanuaryMarch, 1912, together with Impressions and Notes by the Artist (London: William Heinemann, 1913), pp. 7 and 14.

38 Christian Wolmar, The Subterranean Railway: How the London Underground was Built and How it Changed the City Forever (London: Atlantic Books, 2004), p. 70.

${ }^{39}$ Symons, London: A Book of Aspects, p. 9.

${ }^{40}$ Balibar, The Philosophy of Marx, pp. 60-1.

${ }^{41}$ Malcolm Bull, Seeing Things Hidden: Apocalypse, Vision and Totality, p. 26.

42 James, The Art of the Novel, p. 155.

43 Jacques Derrida, 'Generations of a City: Memory, Prophecy, Responsibilities', trans., Rebecca Comay, in Alphabet City, 6: Open City, ed., John Knechtel (Toronto: Anansi Press, 1998), pp. 12 and 16.

${ }^{44}$ James, 'London', p. 225. 